\title{
Hyponatraemia associated with pneumonia or bacterial meningitis
}

\author{
F SHANN AND S GERMER
}

Goroka Hospital, Papua, New Guinea

SUMMARY Serum sodium concentrations were measured in 93 children with pneumonia or bacterial meningitis on their admission to hospital. Hyponatraemia (sodium value $134 \mathrm{mmol} / \mathrm{l}$ or less) was present in $33(45 \%)$ of the 73 children with pneumonia, and in $10(50 \%)$ of the 20 children with bacterial meningitis. Increased secretion of antidiuretic hormone is common in children with pneumonia, as well as in children with meningitis. The maintenance fluid requirement in these children is usually about $50 \mathrm{ml} / \mathrm{kg} / \mathrm{per}$ day, and children with hyponatraemia caused by water overload need even lower fluid intakes. In developing countries, most children with pneumonia and meningitis should be managed without intravenous fluid treatment.

In 1920 it was shown that many children with pneumonia retain water, ${ }^{1}$ and soon afterwards this phenomenon was found to be associated with an increased blood volume and a low plasma chloride value. ${ }^{23}$ These findings are explained by the syndrome of inappropriate secretion of antidiuretic hormone, which has been described in children with pneumonia in three recent reports. ${ }^{4-6}$ The syndrome also occurs in children with meningitis. ${ }^{78}$ These children are unable to excrete a water load, and they may develop pulmonary or cerebral oedema if they are given intravenous fluid, even though the amount given is not excessive for a normal child of the same size.

All the standard paediatric textbooks refer to the danger of dehydration in pneumonia, but none of them mentions the risk of fluid overload..$^{9-12}$ Most of the books, however, refer to the risk of fluid overload in meningitis. ${ }^{9-11}$

Although pneumonia is one of the two commonest causes of death in children in the world, ${ }^{13}$ there is very little information available on the incidence of increased secretion of antidiuretic hormone in children with pneumonia. The two papers and a letter quoted above report a total of only seven cases, ${ }^{4-6}$ and none of these were prospective studies. It was not possible for us to measure serum antidiuretic hormone concentrations in Papua New Guinea. However, in an acutely ill child who has neither excessive sodium loss (for example from diarrhoea) nor excessive water intake (for example from intravenous administration of $5 \%$ dextrose), hyponatraemia is likely to be due to water retention secondary to increased secretion of antidiuretic hormone. ${ }^{14}$ In a prospective study, we measured the serum sodium concentrations in children with pneumonia or meningitis admitted to this hospital.

\section{Patients and methods}

We studied children aged over 28 days admitted to this hospital with pneumonia or bacterial meningitis between April and July 1979. Children with malnutrition or diarrhoea were excluded. Children with pneumonia had moderate to severe disease, with cough, intercostal retraction, and evidence of consolidation on chest radiograph. Bacterial meningitis was diagnosed if bacteria grew from the cerebrospinal fluid, the cerebrospinal fluid polymorph count was greater than $100 / \mu l$, or was greater than $20 / \mu \mathrm{l}$ with either a protein concentration in cerebrospinal fluid greater than $1.0 \mathrm{~g} / \mathrm{l}(100 \mathrm{mg} / 100 \mathrm{ml})$ or glucose less than $2.2 \mathrm{mmol} / \mathrm{l}(40 \mathrm{mg} / 100 \mathrm{ml})$. The diagnosis, age, sex, haemoglobin, and serum sodium concentration were recorded for each child.

Both mother and child were admitted to the hospital, and they shared the same bed, so that breast feeding could continue. All children were treated with chloramphenicol or penicillin, or both. None of the children with pneumonia received intravenous fluids. Half the children with meningitis received about $50 \mathrm{ml} / \mathrm{kg} /$ per day of $4.3 \%$ dextrose in $0 \cdot 18 \%$ saline intravenously as part of a randomised controlled trial (unpublished data). No diuretics or sodium supplements were given. The serum sodium concentration was measured again after six or more 
days in hospital in 18 children who had had a serum sodium concentration of $134 \mathrm{mmol} / \mathrm{l}$ or less on admission.

Serum sodium concentrations were measured with an EEL flame photometer. Data analysis was performed using Statpro Statistical Workstation (Wadsworth Electronic Publishing Company, USA).

\section{Results}

The serum sodium was measured in 73 children with pneumonia and 20 children with meningitis (Fig. 1). There was no significant difference between the serum sodium concentration in children with pneumonia and those with meningitis (MannWhitney $U$ test, $P=0.91$ ), or boys and girls (MannWhitney $U$ test, $P=0 \cdot 63$ ). The age distribution of the children with pneumonia and those with menin-

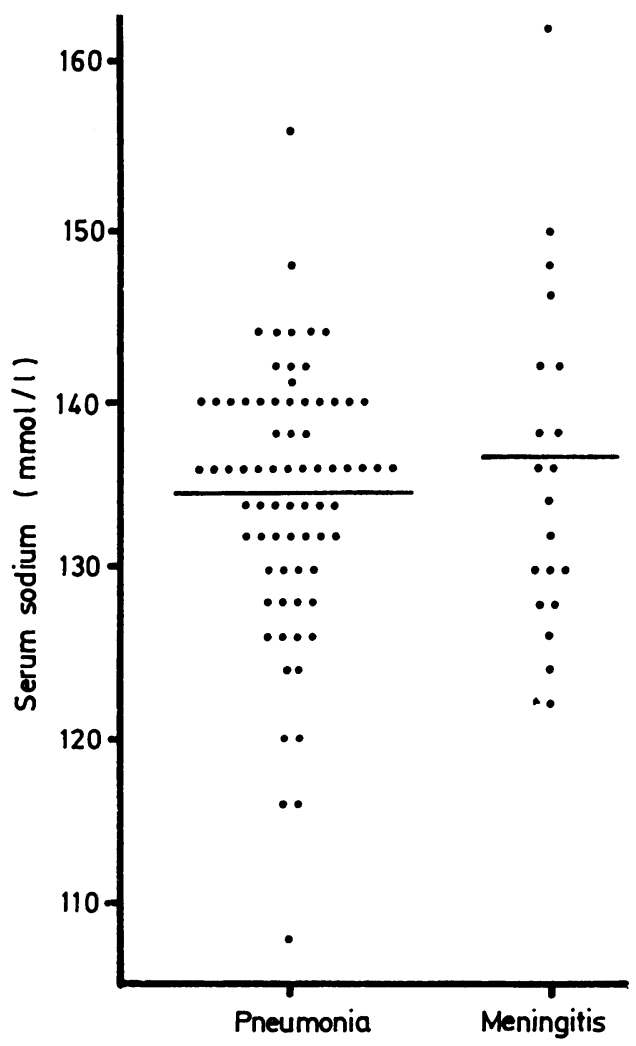

Fig. 1 Serum sodium concentrations in children with pneumonia or meningitis at the time of admission to hospital.

The bars represent the mean values.

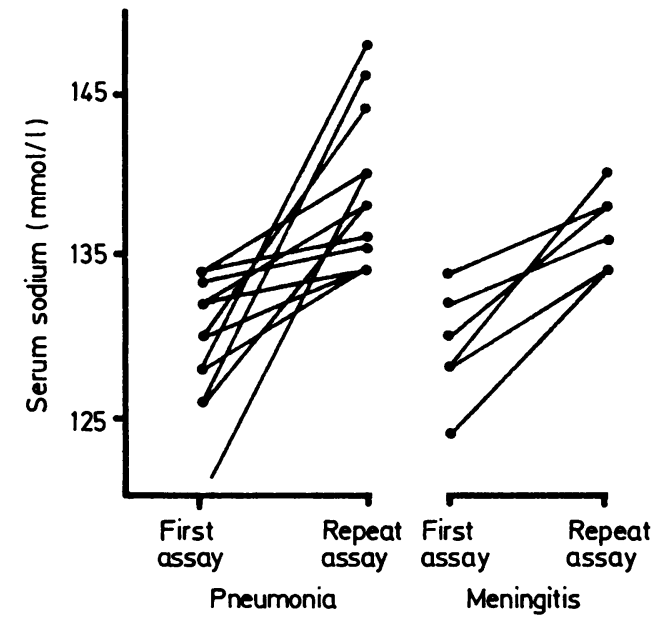

Fig. 2 Serum sodium concentrations in children with a concentration of $134 \mathrm{mmol} / \mathrm{l}$ or less on admission to hospital who had the assay repeated after six days or more.

gitis was similar (Mann-Whitney $\mathrm{U}$ test, $\mathrm{P}=0 \cdot 37$ ). Forty five $(50 \%)$ of the 90 children in whom the age was recorded were aged 1 to 5 months, $25(28 \%)$ were aged 6 to 11 months, $14(16 \%)$ were aged $12-23$ months, and $6(7 \%)$ were aged 24 months or more. All the children less than 24 months of age were breast fed. There was no significant correlation between the serum sodium concentration and age (Spearman's rank correlation coefficient 0.045, $\mathrm{P}=0 \cdot 67$ ) or haemoglobin (Spearman's rank correlation coefficient $0 \cdot 084, \mathrm{P}=0 \cdot 43$ ).

Forty three children had a serum sodium concentration of $134 \mathrm{mmol} / \mathrm{l}$ or less at the time of admission to hospital, and a repeat serum sodium was measured after at least six days in 18 of these (Fig. 2). In every case, the serum sodium concentration had risen to $134 \mathrm{mmol} / \mathrm{l}$ or more, and the repeat values were significantly higher than the admission values (Wilcoxon matched pairs test, $\mathrm{P}<0 \cdot 0002$ ).

\section{Discussion}

It is likely that almost all the children in this study had a bacterial infection, since we selected children with bacterial meningitis and, in children admitted to Goroka Hospital, pneumonia is ususally caused by Haemophilus influenzae or Streptococcus pneumoniae. ${ }^{15}$ Thirty three $(45 \%)$ of the 73 children with pneumonia, and $10(50 \%)$ of the 20 children with bacterial meningitis had a serum sodium concentration of $134 \mathrm{mmol} / \mathrm{l}$ or less at the time of admission to hospital. We were not able to measure urine osmolalities or serum concentrations of antidiuretic 
hormone, but it is likely that the hyponatraemia in these children was due to water retention caused by increased secretion of antidiuretic hormone, since we excluded children with diarrhoea or malnutrition, and the serum sodium rose to $134 \mathrm{mmol} / \mathrm{l}$ or more in all 18 children with hyponatraemia in whom a repeat estimation was performed. No child received a diuretic or sodium supplements. In fact, we may have underestimated the number of children who had increased secretion of antidiuretic hormone, since measurement of the serum sodium concentration will detect only those who have become overhydrated. Hyponatraemia was present in only $50 \%$ of the children with meningitis in our study, while Feigin $e t a l^{7}$ found that $88 \%$ of 50 American children with $H$ influenzae meningitis had evidence of increased secretion of antidiuretic hormone.

The danger of fluid overload in children with bacterial meningitis is widely appreciated, ${ }^{9-11}$ but although the importance of fluid restriction is well recognised in neonates with lung disease ${ }^{16}$ and there have been several case reports of high concentrations of antidiuretic hormone in children over 28 days of age with pneumonia, ${ }^{4-6}$ it has not been appreciated how commonly fluid restriction is indicated in pneumonia in childhood. Most of the standard English language textbooks of paediatrics suggest that an increased fluid intake may be needed in bacterial pneumonia, and none of them warn of the danger of fluid overload. ${ }^{9-12}$ A common mistake in managing children with meningitis or severe pneumonia is to assume that oliguria is due to dehydration, and for extra fluid to be given without excluding increased secretion of antidiuretic hormone, which requires fluid restriction. There is no evidence to support the belief that administration of oral or intravenous fluids will 'loosen the secretions' in pneumonia. Humidification of the air has been shown not to influence the duration of hospital admission of children with pneumonia, ${ }^{17}$ and it may be harmful in children with reactive airways if the air is cooled or water droplets form. ${ }^{18}$

Children with increased secretion of antidiuretic hormone have hyponatraemia because of increased body water, rather than a deficit of sodium. Administration of sodium and frusemide ${ }^{19}$ is indicated only if there are life threatening neurological complications attributable to severe hypo-osmolality. ${ }^{14}$ Most patients are best treated by simply reducing the intake of water. The degree of restriction required is not widely appreciated. A child with oliguria due to increased secretion of antidiuretic hormone who is in a neutral thermal environment will require $45 \mathrm{ml} / \mathrm{kg}$ of water per day to replace insensible losses through the skin and lungs plus
$20 \mathrm{ml} / \mathrm{kg}$ per day to replace urinary losses, less $12 \mathrm{ml} / \mathrm{kg}$ per day gained from the oxidation of carbohydrate and fatty acids,${ }^{14}$ giving a requirement of $53 \mathrm{ml} / \mathrm{kg}$ per day. If the child is already overhydrated, then even less water should be given until the fluid overload is corrected. Insensible water loss will be increased in febrile children but, in a prospective study at this hospital, only $78(17 \%)$ of 460 children with severe pneumonia had an axillary temperature of $39^{\circ} \mathrm{C}$ or more (unpublished data).

There is no doubt that some children with pneumonia and meningitis present with appreciable dehydration. Almost half the children in this study, however, had evidence of fluid overload at the time of admission to hospital, and the proportion with increased secretion of antidiuretic hormone was, in fact, probably even higher than this. These children have a maintenance fluid requirement of only 50 $\mathrm{ml} / \mathrm{kg}$ per day, and fluid restriction (for those already overhydrated) implies intakes of even less than this. In developing countries where infusion pumps are rarely available for giving intravenous fluid, most children with pneumonia or meninigitis should be given their fluids orally and their antibiotics intramuscularly ${ }^{20}$ or orally: this reduces the risk of fluid overload, and avoids the septic complications and the expense of intravenous fluid treatment.

\section{References}

1 Lussky HO, Friedstein H. Water retention in pneumonia. Am J Dis Child 1920;19:337-43.

2 Soule HC, Buckman TE, Darrow DC. Blood volume in fever. $J$ Clin Invest 1928;5:229-42.

${ }^{3}$ Darrow DC, Hartmann AF. Chemical changes occurring in the body as a result of certain diseases. IV. Primary pneumonia in children. Am J Dis Child 1929;37:323-34.

${ }^{4}$ Mor J, Ben-Galmin E, Abrahamov A. Inappropriate antidiuretic hormone secretion in an infant with severe pneumonia. Am J Dis Child 1975;129:133-5.

5 Rosenfeld RG, Reid MJ. Inappropriate antidiuretic hormone secretion. Am J Dis Child 1975;129:1105.

${ }^{6}$ Rivers RPA, Forsling ML, Olver RP. Inappropriate secretion of anti-diuretic hormone in infants with respiratory infections. Arch Dis Child 1981;56:358-63.

${ }^{7}$ Feigin RD, Stechenberg BW, Chang MJ, et al. Prospective evaluation of treatment of Hemophilus influenzae meningitis $J$ Pediatr 1976;88:542-8.

${ }^{8}$ Kaplan SL, Feigin RD. The syndrome of inappropriate secretion of antidiuretic hormone in children with bacterial meningitis. J Pediatr 1978;92:758-61.

9 Forfar JO, Arneil GC. Textbook of paediatrics. 2nd ed. Edinburgh: Churchill Livingstone, 1978:515,1203.

${ }^{10}$ Behrman RE, Vaughan VC. Nelson: textbook of paediatrics. Philadelphia: Saunders, 1983:623,1049.

"Rudolph AM, Hoffman JIE, Axelrod S. Pediatrics. 17th ed. Norwalk: Appleton-Century-Crofts, 1982:519,1440.

12 Jelliffe DB, Stanfield JP. Diseases of children in the subtropics and tropics. 3rd ed. London: Arnold, 1978:277,369-70.

13 Chretien J, Holland W, Macklem P, Murray J, Woolcock A Acute respiratory infections in children: a global public-health problem. N Engl J Med 1984;310:982-4. 
14 Winters RW, ed. The body fluids in pediatrics. Boston: Little Brown, 1973:124,434-6.

15 Shann F, Gratten M, Germer S, Linnemann V, Hazlett D, Payne D. The aetiology of pneumonia in children in Goroka Papua New Guinea. Lancet 1984;ii:537-41.

16 Bland RD. Edema formation in the newborn lung. Clin Perinatol 1982;9:593-611.

${ }^{17}$ Kelsch RC, Barr M, DeMuth GR. Mist therapy in lower respiratory tract infection: a controlled study. Am J Dis Child 1965;109:495-9.

${ }^{18}$ Neijens HJ, Duiverman EJ, Kerrebijn KF. Bronchial responsiveness in children. Pediatr Clin North Am 1983;30:829-46.
${ }^{19}$ Decaux G, Waterlot Y, Genette F, Hallemans R, Demanet JC Inappropriate secretion of antidiuretic hormone treated with frusemide. $\mathrm{Br}$ Med J 1982;285:89-90.

20) Anonymous. Intramuscular or intravenous antibiotics? Lancet $1984 ; \mathbf{i}: 660-2$

Correspondence to Dr F Shann, Intensive Care Unit, Royal Children's Hospital, Parkville, Victoria 3052, Australia.

Received 30 April 1985

\section{Shredding of manuscripts}

From 1 January 1986 articles submitted for publication will not be returned if the paper is rejected unless this is requested at the time of submission. Authors whose papers are rejected will be advised of the decision; the manuscripts will be kept under security for three months to deal with any enquiries and then destroyed by shredding. 